\title{
CORRECTION
}

\section{Correction to: Subarachnomegaly—venous congestion of infancy}

\author{
Laura V. Sainz $^{1,2} \cdot$ Martin U. Schuhmann ${ }^{2}$
}

Published online: 6 December 2021

(c) Springer-Verlag GmbH Germany, part of Springer Nature 2021

\section{Child's Nervous System (2021) 37:3455-3463 https://doi.org/10.1007/s00381-021-05328-z}

In this article the author name "Martin U. Schuhmann" was incorrectly written as "Martin V. Schuhmann".

The original article has been corrected.

Publisher's Note Springer Nature remains neutral with regard to jurisdictional claims in published maps and institutional affiliations.

The original article can be found online at https://doi.org/10.1007/ s00381-021-05328-z.

Laura V. Sainz

lsainz@braintools.es

1 Institute of Neuroinformatics, ETH, Zürich, Switzerland

2 Division of Pediatric Neurosurgery, Department

of Neurosurgery, University Hospital of Tübingen, Tübingen,

Germany 